\title{
KPI Selection Using The AHP Method on SOE X
}

\author{
Regine Rahmada Berliana, Budi Sulistyo, and Litasari Widyastuti Suwarsono \\ School of Industrial and System Engineering, Telkom University, Bandung, Indonesia \\ e-mail: regineberliana19@gmail.com
}

\begin{abstract}
PT X (Persero), a state-owned enterprise under the Ministry of Indonesia SOEs (KBUMN), is required to set up the Key Performance Indicators (KPI) Regulations based on the Assessment Criteria for Performance Excellence (KPKU). The re-weighting of KPIs using the Analytical Hierarchy Process (AHP) method is conducted by selecting performance indicators based on five perspectives. Based on the study results, selected performance measures for financial and market perspectives are cash position, cash-to-cash time cycle, income, and financial operations efficiency. Selected performance measures for customer focus perspective are customer complaints, complaint management, effective complaint resolution, and warranty claims; customer satisfaction and dissatisfaction; and retention, acquisition, and loss of customers and customer accounts. Selected performance measures for product and process effectiveness perspective are product performance, work system performance, improved performance of administrative functions and other supporting functions; and indicators of internal responsiveness. Selected performance measures for the perspective of workforce focus are turnover and effectiveness of training, retraining, or cross-functional training. Selected performance measures for leadership, governance, and community responsibility perspectives are the company's contribution to social welfare, achievements worthy of note in this field; and environmental, legal, and regulatory compliance.
\end{abstract}

Keywords - AHP, Criteria Selection, KPI, KPKU, SOE

\section{INTRODUCTION}

$\mathrm{N}^{\mathrm{o}}$ OWADAYS, changes in a company need a better stage, especially regarding performance evaluation criteria. Since performance appraisal is a structured and official explanation regarding the quality of work of employees and companies. Performance appraisal criteria have a significant function for the internal and external parts of the company because if it is not well determined, it can reduce the company's credibility since there is no evaluation [1].

One of the institutions that made changes to the performance evaluation criteria is the Ministry of StateOwned Enterprises (KBUMN). Through a new regulation [2], KBUMN conveys guidelines for determining Key Performance Indicators (KPI) and Assessment Criteria from Performance Excellence (KPKU) for SOEs as shown in Fugure 1., that are adapted from the Baldrige Excellence Framework (BEF), a criterion that is widely used by countries in the world to measure and improve work performance [3].

Through the use of the KPKU framework in determining KPIs, SOEs are expected to improve the effectiveness of controlling their performance and also be able to optimize the potential capitalization efforts and to accelerate the growth of

\begin{tabular}{|l|c|c|}
\hline \multirow{2}{*}{\multicolumn{1}{|c|}{ Perspective }} & \multicolumn{2}{c|}{$\begin{array}{c}\text { Number of Selected Performance } \\
\text { Sizes }\end{array}$} \\
\cline { 2 - 3 } & Minimum & Maximum \\
\hline Financial and Market & 3 & 5 \\
\hline Customer Focus & 2 & 3 \\
\hline Product and Process Effectiveness & 3 & 5 \\
\hline Workforce Focus & 2 & 3 \\
\hline $\begin{array}{l}\text { Leadership, Governance, and Social } \\
\text { Responsibility }\end{array}$ & 3 & 5 \\
\hline \multicolumn{1}{|c|}{ Total } & 13 & 21 \\
\hline
\end{tabular}

Figure 1. Conditions of Number of Performances.

\begin{tabular}{|c|c|c|c|}
\hline Finantial Ratio & $\mathbf{2 0 1 7}$ & $\mathbf{2 0 1 8}$ & \% Change \\
\hline Net Profit Margin & $2.86 \%$ & $3.21 \%$ & $0.35 \%$ \\
\hline Return on Investment (ROI) (\%) & $162.66 \%$ & $162.15 \%$ & $-0,51 \%$ \\
\hline Return on Assets (ROA) (\%) & $78.20 \%$ & $86.98 \%$ & $8.78 \%$ \\
\hline Return on Equity (ROE) (\%) & $15.54 \%$ & $18.78 \%$ & $3.24 \%$ \\
\hline
\end{tabular}

Figure 2. Financial Performance Ratio of PT X.

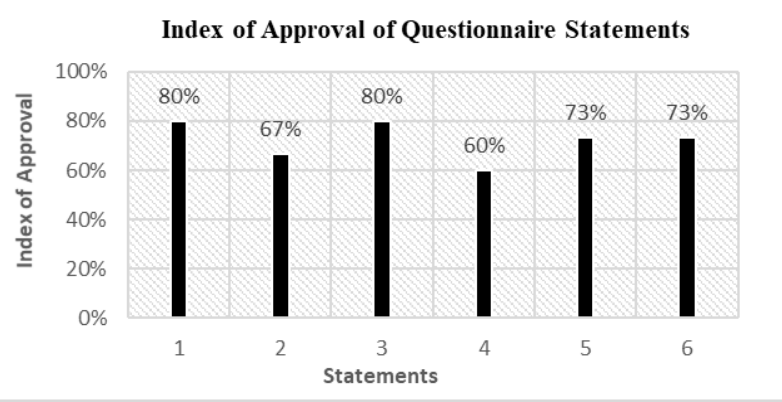

Figure 3. Index of Approval of Questionnaire Statements.

SOE performance in dealing with the Asean Economic Community (MEA). The intended SOEs are all business sectors and types of SOEs in the form of State-Owned Company (Persero), Public Company (Perum), and a Bureau of Companies (Perjan) totaling 118 business entities in 2018.

The KPIs function is to measure and assess the performance of the Board of Directors in managing a company based on the KPKU approach consists of five perspectives, namely product and process effectiveness; customer focus; financial and market; workforce focus; and leadership, governance, and social responsibility [2]. The five perspectives have a range and number of different performance measures in accordance with Figure 1. The related SOEs will choose performance measures that are in line with the company's identity. However, since the KPKU is adapted from the Baldrige Excellence Framework (BEF) 
The $1^{\text {st }}$ International Conference on Business and Engineering Management (IConBEM 2020)

February $1^{\text {st }} 2020$, Institut Teknologi Sepuluh Nopember, Surabaya, Indonesia

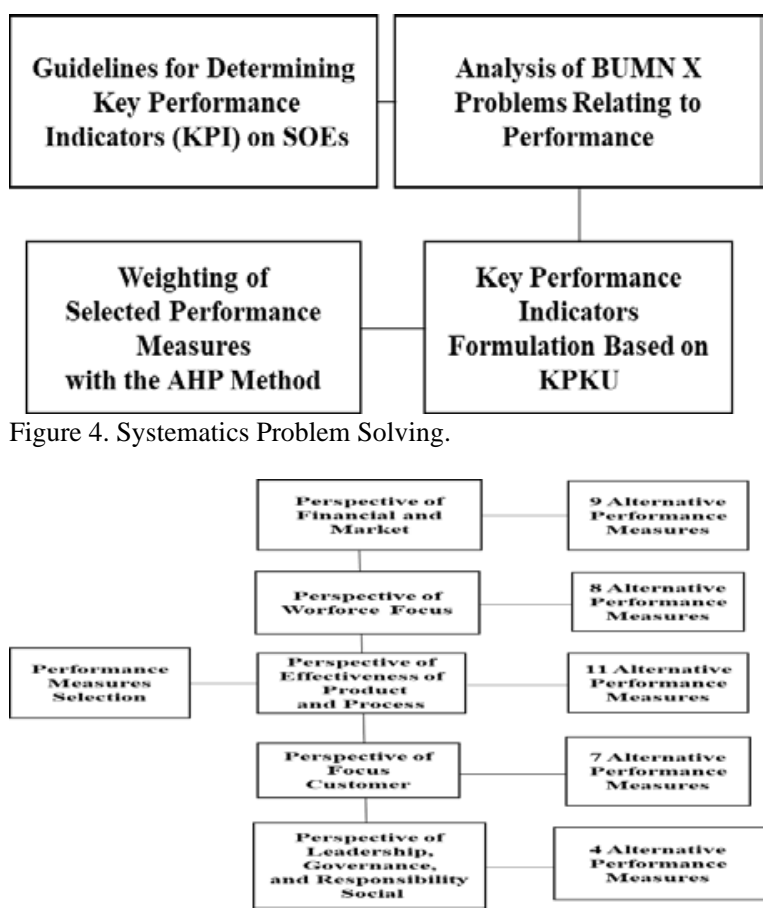

Figure 5. Process Hierarchy Structure.

\begin{tabular}{|c|c|c|c|c|c|c|}
\hline & $A_{1}$ & $A_{2}$ & ... & $A_{n}$ & $\begin{array}{c}\text { Calculation } \\
\text { of Raw }\end{array}$ & $\begin{array}{l}\text { Priority } \\
\text { Vector }\end{array}$ \\
\hline$A_{1}$ & A1/W1 & $A 1 / W 2$ & $\ldots$ & $A 1 / W n$ & A & $\mathrm{A} / \mathrm{X}$ \\
\hline$A_{2}$ & $A 2 / W 1$ & $A 2 / W 2$ & $\ldots$ & A2/Wn & $B$ & $\mathrm{~B} / \mathrm{X}$ \\
\hline$\ldots$ & $\ldots$ & $\ldots$ & $\ldots$ & $\ldots$ & $\ldots$ & $\ldots / \mathrm{X}$ \\
\hline$A_{n}$ & $A n / W 1$ & $A n / W 2$ & $\ldots$ & $A n / W n$ & $\mathrm{~N}$ & $\mathrm{~N} / \mathrm{X}$ \\
\hline Total & & & & & $\mathrm{X}$ & \\
\hline
\end{tabular}

Figure 6. Calculation of Priority Vector.

directly without any adjustments to the work culture in Indonesia [4] some problems exist Unlike other countries such as Singapore, Thailand, and Malaysia, which already adapted and updated the BEF, the implementation could run optimally [3]. Besides, KBUMN does not provide official guidance on how to select or weight performance measures so that the perceived impact is optimal for the company. Based on the data in Figure 2., it is known that PT X has a negative Return on Investment (ROI) and the ratio of other financial performance changes from 2017 to 2018 is not much [5].

Therefore, a questionnaire is distributed to 3 respondents of PT X which is used to determine the extent of the implementation and effectiveness of KPIs from the performance indicators in the Assessment Criteria for Performance Excellence (KPKU). According to the data obtained through a questionnaire (see Figure 3.), although some statements have been categorized as useful, such as the value of the selection of performance measures (statement 1 ) and evaluations of performance indicators which have been conducted regularly (statement 3 ), the implementation and effectiveness of KPI in PT X has not been maximized. This is shown by the systematic weighting (statement 2) that has not been done well, the number of performance indicators
Table 1.

Importance Level of Criteria

\begin{tabular}{|c|c|c|c|}
\hline $\begin{array}{c}\text { Level of } \\
\text { Importance }\end{array}$ & \multicolumn{3}{|c|}{$\begin{array}{l}\text { Additional } \\
\text { Information }\end{array}$} \\
\hline 1 & \multicolumn{3}{|c|}{ Both elements are equally important } \\
\hline $\begin{array}{r}7 \\
9 \\
2,4,6,8\end{array}$ & \multicolumn{3}{|c|}{$\begin{array}{l}\text { One element is slightly more important } \\
\text { than the other elements } \\
\text { One element is more important than the } \\
\text { other elements } \\
\text { One element is very important than the } \\
\text { other elements } \\
\text { Absolute more important } \\
\text { The middle value between two opinions } \\
\text { that are side by side }\end{array}$} \\
\hline \multicolumn{4}{|c|}{$\begin{array}{c}\text { Table } 2 . \\
\text { Results of Selection of Number of Performance Measures for Each } \\
\text { Perspective }\end{array}$} \\
\hline Perspective & $\begin{array}{l}\text { Minimum } \\
\text { Amount }\end{array}$ & $\begin{array}{l}\text { Maximum } \\
\text { Amount }\end{array}$ & $\begin{array}{l}\text { Selected } \\
\text { Amount }\end{array}$ \\
\hline $\begin{array}{l}\text { Financial and } \\
\text { Markets }\end{array}$ & 3 & 5 & 4 \\
\hline $\begin{array}{l}\text { Customer Focus } \\
\text { Product and }\end{array}$ & 2 & 3 & 3 \\
\hline $\begin{array}{l}\text { Process } \\
\text { Effectiveness }\end{array}$ & 3 & 5 & 4 \\
\hline $\begin{array}{l}\text { Workforce } \\
\text { Focus } \\
\text { Leadership, }\end{array}$ & 2 & 3 & 2 \\
\hline $\begin{array}{l}\text { Governance and } \\
\text { Responsibility } \\
\text { Community }\end{array}$ & 3 & 5 & 3 \\
\hline
\end{tabular}

that are not in accordance with the provisions (statement 4), perspective weights that are not yet in-line with the company's business growth (statement 5), and current financial and non-financial performance that have not yet been achieved (statement 6 ). The following are the results of the questionnaire for the preliminary study:

Through this fact, it is necessary to select and weight performance measures that can optimize growth and sustainability performance efforts as well as increase company competitiveness. It because systematic weighting has not been carried out, the number of performance indicators that are not under the provisions, the weight of perspective that is not in accordance with the company's business growth, and current performance indicators that have not been achieved yet.

\section{II.METHOD}

\section{A. Literature Review}

\section{1) Measurement of Company Performance}

Measuring company performance is a process of quantifying the efficiency and effectiveness of actions taken against the company so that it can be seen the increase and decrease performance metrics that have been set to measure company performance [6].

\section{2) Baldridge Excellence Framework}

Baldridge Excellence Framework is a framework that is used for all work perspectives in the company, not only limited to the perspective of product and process quality [3]. 
The $1^{\text {st }}$ International Conference on Business and Engineering Management (IConBEM 2020)

February $1^{\text {st }} 2020$, Institut Teknologi Sepuluh Nopember, Surabaya, Indonesia

\begin{tabular}{|l|c|}
\hline $\begin{array}{c}\text { Perspectives for Rapid Growth in Corporate Business } \\
(>\mathbf{1 5 \%})\end{array}$ & Weight \\
\hline Financial and Markets & $20 \%$ \\
\hline Customer Focus & $24 \%$ \\
\hline Product and Process Effectiveness & $18 \%$ \\
\hline Workforce Focus & $20 \%$ \\
\hline $\begin{array}{l}\text { Leadership, Governance and Responsibility } \\
\text { Community }\end{array}$ & $18 \%$ \\
\hline \multicolumn{1}{|c|}{ Total } & $100 \%$ \\
\hline
\end{tabular}

Figure 7. Perspective Weights for Companies with Rapid Growt.

\begin{tabular}{|l|c|}
\hline $\begin{array}{l}\text { Perspectives for Medium Growth in Company Business } \\
\text { (5--15\%) }\end{array}$ & Weight \\
\hline Financial and Markets & $24 \%$ \\
\hline Customer Focus & $22 \%$ \\
\hline Product and Process Effectiveness & $20 \%$ \\
\hline Workforce Focus & $17 \%$ \\
\hline $\begin{array}{l}\text { Leadership, Governance and Responsibility } \\
\text { Community }\end{array}$ & $17 \%$ \\
\hline \multicolumn{1}{|c|}{ Total } & $100 \%$ \\
\hline
\end{tabular}

Figure 8. Perspective Weight for Companies with Medium Growth.

\begin{tabular}{|l|c|}
\hline $\begin{array}{c}\text { Perspectives for Relatively Slow Growth in Corporate } \\
\text { Business (0--5\%) }\end{array}$ & Weight \\
\hline Financial and Markets & $26 \%$ \\
\hline Customer Focus & $20 \%$ \\
\hline Product and Process Effectiveness & $22 \%$ \\
\hline Workforce Focus & $16 \%$ \\
\hline $\begin{array}{l}\text { Leadership, Governance and Responsibility } \\
\text { Community }\end{array}$ & $16 \%$ \\
\hline \multicolumn{1}{|c|}{ Total } & $100 \%$ \\
\hline
\end{tabular}

Figure 9. Perspective Weight for Companies with Slow Growth.

\begin{tabular}{|l|c|}
\hline \multicolumn{1}{|c|}{$\begin{array}{c}\text { Perspectives for Negative Growth in Company } \\
\text { Business (<0\%) }\end{array}$} & Weight \\
\hline Financial and Markets & $28 \%$ \\
\hline Customer Focus & $18 \%$ \\
\hline Product and Process Effectiveness & $24 \%$ \\
\hline Workforce Focus & $15 \%$ \\
\hline $\begin{array}{l}\text { Leadership, Governance and Responsibility } \\
\text { Community }\end{array}$ & $15 \%$ \\
\hline \multicolumn{1}{|c|}{ Total } & $100 \%$ \\
\hline
\end{tabular}

Figure 10. Perspective Weight for Companies with Negative Growth.

\section{3) Key Performance Indicators}

Key Performance Indicators (KPI) are measures that focus on the most significant elements of company performance that determine the company's success in the present and future [2].

\section{4) Geomean}

Geometric mean is a calculation technique to get an answer from the weighting average grading given by some respondents [7]

$\mathrm{G}=\sqrt[n]{X 1 \cdot X 2 \cdot X 3 \ldots X n}$

Additional information:

$\mathrm{G}=$ Geomean

$\mathrm{Xn}=1$ st assessment, 2nd assessment, 3rd assessment,..n

$\mathrm{n}$ = Amount of assessment

The reason for using Geomean is that the respondents needed to complete the pair-wise comparison questionnaire is 3 respondents. Thus, collective decisions are needed to complete the weighting results in AHP [8]. Questionnaires were filled out by 3 experts. The reason the respondents numbered 3 people is according to research conducted by Sulistyo (2019) the average respondent for AHP is 2 to 10 people. Therefore, the time needed for data calculation is
Table 3.

Vector Priority Results for Financial and Market Perspectives

\begin{tabular}{cccc}
\hline \hline $\begin{array}{c}\text { PERFORMANCE } \\
\text { MEASURE }\end{array}$ & $\begin{array}{c}\text { Priority } \\
\text { Vector }\end{array}$ & $\begin{array}{c}\text { PERFORMANCE } \\
\text { MEASURE }\end{array}$ & $\begin{array}{c}\text { Priority } \\
\text { Vector }\end{array}$ \\
\hline Income & 0,153 & $\begin{array}{c}\text { Cycle time } \\
\text { Cash-to-Cash } \\
\text { Revenue Per } \\
\text { Stock }\end{array}$ & 0,185 \\
Cash Position & 0,080 & $\begin{array}{c}\text { Financial } \\
\text { Operations } \\
\text { Efficiency }\end{array}$ & 0,126 \\
Net Assets & 0,051 & $\begin{array}{c}\text { (collection, billing, } \\
\text { receivables) } \\
\text { Financial } \\
\text { Returns }\end{array}$ & 0,102 \\
Debt Leverage & 0,067 & & \\
\hline \hline
\end{tabular}

Table 4.

Priority Vector Results for a Customer Focus Perspective

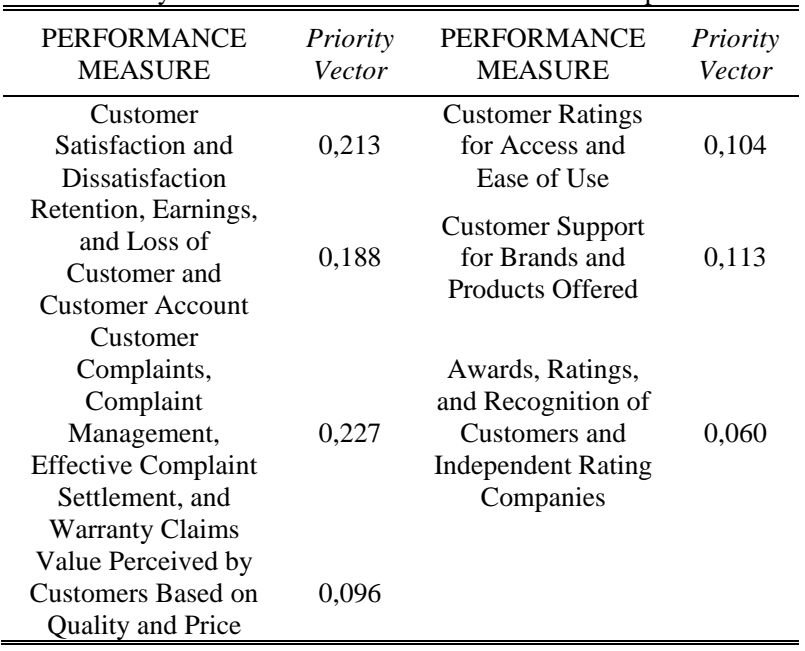

quick and should be an odd number of experts so if there is a difference of opinion it can be resolved by voting.

\section{5) Analytical Hierarchy (AHP)}

AHP is used to derive the ratio scale from several discrete and continuous pair comparisons [9]. The steps in doing the AHP method, namely define the problem and determine goals, structure the hierarchy of criteria to become many alternatives, make a pairwise comparison matrix for the weight contribution of each alternative to the criteria of the same level of influence. The importance level of criteria can be seen in Table 1. as follows:

Then, calculates the Geomean values of several respondents; normalizing data, by dividing the value of each element in the paired matrix with the total value of each column, calculates the priority vector value. From the prioritization process, later the value of pairwise comparison matrix elements will be summed up to the bottom. After that, the value of the elements will be divided by the results of the summation of the column earlier or called normalization. The results of normalization are summed in rows and divided by the amount in columns to get priority vectors. As mentioned in the Table 1., for the normalization of these elements are expressed in the form $\mathrm{A} 1 / \mathrm{W}_{1}, \mathrm{~A} 1 / \mathrm{W}_{2}, \mathrm{~A} 1 / \mathrm{W}_{3}, \ldots, \mathrm{Wn}$ then for the assessment of the level of importance, for example, A1 with $\mathrm{A} 2 \frac{A 1}{W 2}=\mathrm{a}$, which will get a matrix-like in Figure 6 . below: 
The $1^{\text {st }}$ International Conference on Business and Engineering Management (IConBEM 2020)

February $1^{\text {st }} 2020$, Institut Teknologi Sepuluh Nopember, Surabaya, Indonesia

Table 5.

Priority Vector Results for Product and Process Effectiveness Perspectives

\begin{tabular}{|c|c|c|c|}
\hline $\begin{array}{l}\text { PERFORMANCE } \\
\text { MEASURE }\end{array}$ & Priority Vector & $\begin{array}{l}\text { PERFORMANCE } \\
\text { MEASURE }\end{array}$ & $\begin{array}{c}\text { Priority } \\
\text { Vector }\end{array}$ \\
\hline $\begin{array}{l}\text { Internal Quality } \\
\text { Measurement }\end{array}$ & 0,05 & Response Time & 0,08 \\
\hline $\begin{array}{l}\text { Product } \\
\text { Performance }\end{array}$ & 0,16 & $\begin{array}{l}\text { Data Collected } \\
\text { from Customer by } \\
\text { Other Companies } \\
\text { Customer Survey }\end{array}$ & 0,04 \\
\hline Disability Rate & 0,09 & $\begin{array}{c}\text { about Product and } \\
\text { Service } \\
\text { Performance }\end{array}$ & 0,07 \\
\hline Usage Error & 0,05 & $\begin{array}{c}\text { Increased } \\
\text { Performance of } \\
\text { Administrative } \\
\text { Functions and } \\
\text { other Support } \\
\text { Functions }\end{array}$ & 0,12 \\
\hline $\begin{array}{l}\text { Work System } \\
\text { Performance which } \\
\text { Shows Increased } \\
\text { Cost Savings and } \\
\text { Higher } \\
\text { Productivity }\end{array}$ & 0,15 & $\begin{array}{l}\text { Reduced Emission } \\
\text { or Energy } \\
\text { Consumption, } \\
\text { Reduction of } \\
\text { Waste Flow, Use } \\
\text { of By Products, } \\
\text { and Recycling }\end{array}$ & 0,09 \\
\hline $\begin{array}{l}\text { Indicator of } \\
\text { Internal Speed, } \\
\text { such as Cycle Time } \\
\text { Production } \\
\text { Flexibility, Waiting } \\
\text { Time, Installation } \\
\text { Time, and Time to } \\
\text { Market }\end{array}$ & 0,10 & & \\
\hline
\end{tabular}

Table 6.

Priority Vector Results for Workforce Focus Perspectives

\begin{tabular}{|c|c|c|c|}
\hline $\begin{array}{l}\text { PERFORMANCE } \\
\text { MEASURE }\end{array}$ & $\begin{array}{l}\text { Priority } \\
\text { Vector }\end{array}$ & $\begin{array}{l}\text { PERFORMANCE } \\
\text { MEASURE }\end{array}$ & $\begin{array}{c}\text { Priority } \\
\text { Vector }\end{array}$ \\
\hline Work safety & 0,33 & Labor Complaints & 0,14 \\
\hline Absence & 0,14 & $\begin{array}{l}\text { Effectiveness of } \\
\text { Training, Retraining, } \\
\text { or Cross-Functional } \\
\text { Training in Meeting } \\
\text { the Capability and } \\
\text { Capacity } \\
\text { Requirements of the } \\
\text { Company's } \\
\text { Workforce }\end{array}$ & 0,36 \\
\hline Turnover & 0,39 & $\begin{array}{c}\text { Workforce } \\
\text { Effectiveness of } \\
\text { Independent Workers } \\
\text { (Self Directing) }\end{array}$ & 0,17 \\
\hline Satisfaction & 0,28 & $\begin{array}{c}\text { Effectiveness of } \\
\text { Trade-Management } \\
\text { Partnership } \\
\text { Partnerships } \\
\end{array}$ & 0,17 \\
\hline
\end{tabular}

Last, test the consistency of the hierarchy. If it does not meet the $\mathrm{CR}$ rule $<0.1$ then the assessment must be repeated. To test consistency [9] each paired matrix must follow the calculation steps as follows:

\section{1) Calculation of Maximum Lambda ( $\lambda)$}

The steps to find the maximum lambda $(\lambda)$ are perform the calculation of times results by multiplying normalization results in rows with priority vectors in columns and the times results divided by priority vector

2) Calculate the Consistency Index (CI)

Following is the Consistency Index (CI) formula:
Table 7.

Priority Vector Results for Community Leadership, Governance and Responsibility Perspectives

\begin{tabular}{lc}
\hline \hline \multicolumn{1}{c}{ PERFORMANCE MEASURE } & Priority Vector \\
\hline $\begin{array}{l}\text { Environmental, Legal and Regulatory } \\
\text { Compliance }\end{array}$ & 0,24 \\
$\begin{array}{l}\text { Results of Government Oversight } \\
\text { Audit or Funding Institutions }\end{array}$ & 0,23 \\
$\begin{array}{l}\text { Worthy achievements to note in this } \\
\text { field }\end{array}$ & 0,25 \\
$\begin{array}{l}\text { Company's contribution to social } \\
\text { welfare and benefits and support to the } \\
\text { main community }\end{array}$ & 0,28 \\
\hline \hline
\end{tabular}

Table 8.

Perspective Weight According to the Company's Business Growth for Financial and Market Perspectives

\begin{tabular}{|c|c|c|c|c|}
\hline Perspective & $\begin{array}{l}\text { Weight } \\
\text { from } \\
\text { KPKU }\end{array}$ & $\begin{array}{c}\text { Selected } \\
\text { Performance } \\
\text { Measures }\end{array}$ & $\begin{array}{l}\text { Weight } \\
\text { Based } \\
\text { on } \\
\text { KPKU } \\
\end{array}$ & $\begin{array}{l}\text { Weight } \\
\text { from } \\
\text { AHP }\end{array}$ \\
\hline \multirow{6}{*}{$\begin{array}{l}\text { Financial and } \\
\text { Markets }\end{array}$} & \multirow{6}{*}{$24 \%$} & Cash Position & $7,1 \%$ & 0,194 \\
\hline & & $\begin{array}{l}\text { Cash-to-Cash } \\
\text { Cycle Time }\end{array}$ & $6,7 \%$ & 0,185 \\
\hline & & Income & $5,6 \%$ & 0,153 \\
\hline & & Financial & & \\
\hline & & Operations & & \\
\hline & & $\begin{array}{l}\text { Efficiency } \\
\text { (collection, } \\
\text { billing, } \\
\text { receivables) }\end{array}$ & $4,6 \%$ & 0,126 \\
\hline
\end{tabular}

Table 9

Perspective Weight According to the Company's Business Growth for Customer Focus Perspectives

\begin{tabular}{|c|c|c|c|c|}
\hline Perspective & $\begin{array}{l}\text { Weight } \\
\text { from } \\
\text { KPKU }\end{array}$ & $\begin{array}{c}\text { Selected } \\
\text { Performance } \\
\text { Measures }\end{array}$ & $\begin{array}{l}\text { Weight } \\
\text { Based } \\
\text { on } \\
\text { KPKU }\end{array}$ & $\begin{array}{c}\text { Weight } \\
\text { from } \\
\text { AHP }\end{array}$ \\
\hline $\begin{array}{l}\text { Customer } \\
\text { Focus }\end{array}$ & $22 \%$ & $\begin{array}{l}\text { Customer } \\
\text { Satisfaction and } \\
\text { Dissatisfaction } \\
\text { Retention, } \\
\text { Earnings, and } \\
\text { Loss of } \\
\text { Customer and } \\
\text { Customer } \\
\text { Account } \\
\text { Complaints, } \\
\text { Complaint } \\
\text { Management, } \\
\text { Effective } \\
\text { Complaint } \\
\text { Settlement, and } \\
\text { Warranty } \\
\text { Claims }\end{array}$ & $6,6 \%$ & 0,213 \\
\hline
\end{tabular}

$$
\mathrm{CI}=\frac{\lambda \max -\mathrm{n}}{(n-1)}
$$

Additional information: $\mathrm{CI}$ = ratio of deviation of consistency (consistency index)

$\lambda \max =$ The largest eigenvalue of the order matrix or the average of the product times divided by priority vector $\mathrm{n}=$ Order matrix or number of elements. The eigenvalue is obtained by adding up the multiplication results of the number of columns with priority vectors, then taking the largest eigenvalue. 
The $1^{\text {st }}$ International Conference on Business and Engineering Management (IConBEM 2020)

February $1^{\text {st }} 2020$, Institut Teknologi Sepuluh Nopember, Surabaya, Indonesia

Table 10.

Perspective Weight According to the Company's Business Growth for Workforce Focus Perspectives

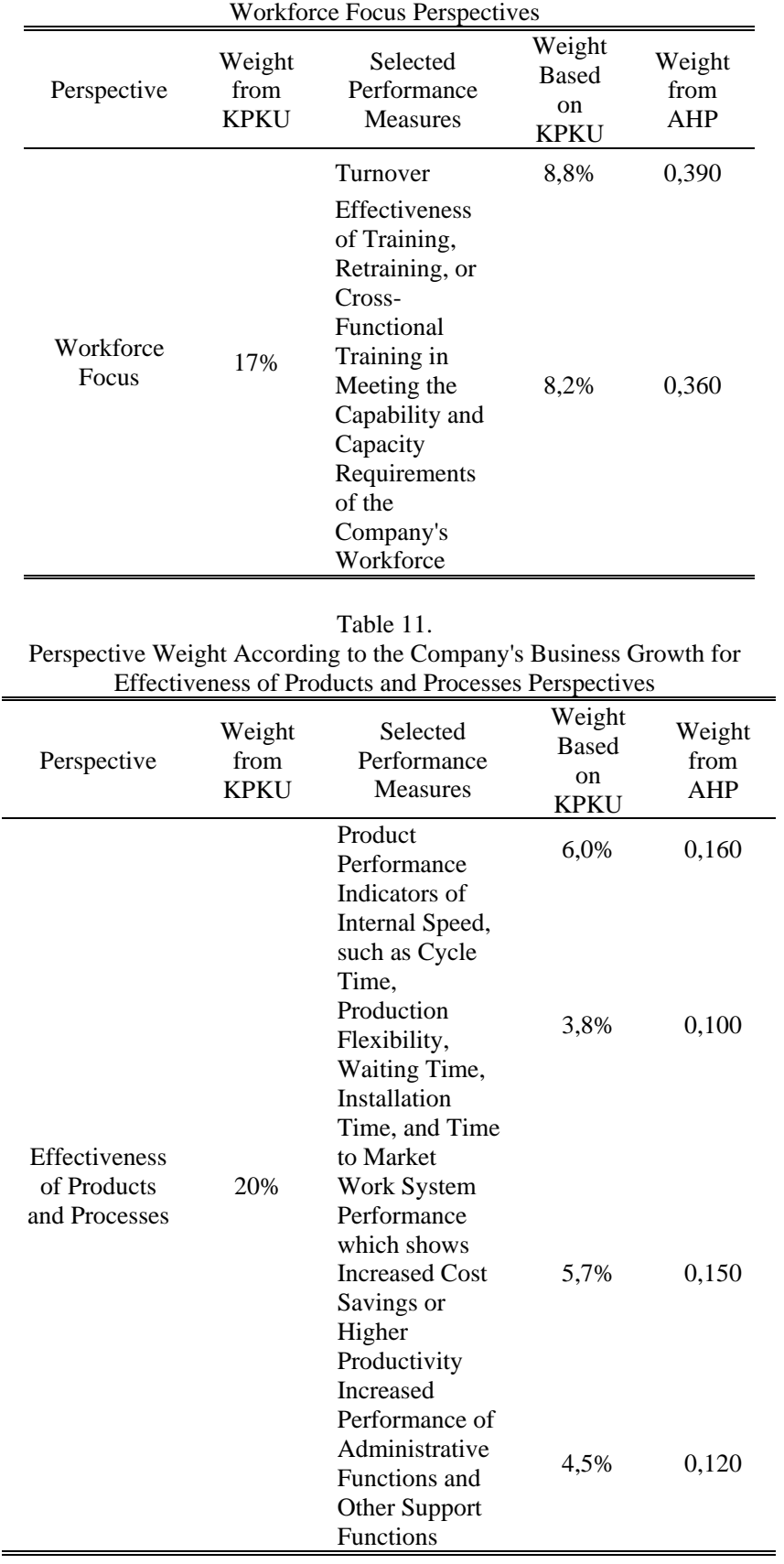

3) Random Index Calculation (RI)

Here is the Random Index (RI) formula:

$$
\mathrm{RI}=\frac{1,98(n-2)}{n}
$$

Additional information:

$\mathrm{n}=$ Order matrix or number of elements

a. Calculation of Consistency Ratio (CR)

Here is the Consistency Ratio (CR) formula:

$$
\mathrm{CR}=\frac{\mathrm{CI}}{R I}
$$

Additional information:CR = Consitency Ratio; RI = Random Index.
Table 12.

Perspective Weight According to the Company's Business Growth for Community Leadership, Governance and Responsibility Perspectives

\begin{tabular}{|c|c|c|c|c|}
\hline Perspective & $\begin{array}{l}\text { Weight } \\
\text { from } \\
\text { KPKU }\end{array}$ & $\begin{array}{c}\text { Selected } \\
\text { Performance } \\
\text { Measures }\end{array}$ & $\begin{array}{l}\text { Weigh } \\
\text { Based } \\
\text { on } \\
\text { KPKU }\end{array}$ & $\begin{array}{l}\text { Weight } \\
\text { from } \\
\text { AHP }\end{array}$ \\
\hline $\begin{array}{l}\text { Community } \\
\text { Leadership, } \\
\text { Governance } \\
\text { and } \\
\text { Responsibility }\end{array}$ & $17 \%$ & $\begin{array}{l}\text { Environmental, } \\
\text { Legal and } \\
\text { Regulatory } \\
\text { Compliance } \\
\text { Worthy } \\
\text { achievements } \\
\text { to note in this } \\
\text { field } \\
\text { Company's } \\
\text { Contribution to } \\
\text { Social Welfare } \\
\text { and Benefits } \\
\text { and Support to } \\
\text { Main } \\
\text { Communities }\end{array}$ & $5 \%$ & 0,240 \\
\hline \multicolumn{5}{|c|}{$\begin{array}{l}\text { Table } 13 \text {. } \\
\text { Assessment of the Existing Performance at SOE X }\end{array}$} \\
\hline \multicolumn{2}{|c|}{ Perspective } & $\begin{array}{l}\text { Maximum } \\
\text { Point }\end{array}$ & \multicolumn{2}{|c|}{$\begin{array}{l}\text { Score Obtained by } \\
\text { the Company }\end{array}$} \\
\hline \multicolumn{2}{|c|}{ Financial and Markets } & $10 \%$ & \multicolumn{2}{|c|}{$9 \%$} \\
\hline \multicolumn{2}{|c|}{ Customer Focus } & Product and Process & \multicolumn{2}{|c|}{$19 \%$} \\
\hline \multicolumn{2}{|c|}{ Effectiveness } & $25 \%$ & \multicolumn{2}{|c|}{$20,96 \%$} \\
\hline Workforce Foc & & $20 \%$ & \multicolumn{2}{|c|}{$19 \%$} \\
\hline $\begin{array}{l}\text { Community Le } \\
\text { Governance an } \\
\text { Responsibility }\end{array}$ & $\begin{array}{l}\text { ership, } \\
\text { spective }\end{array}$ & $25 \%$ & \multicolumn{2}{|c|}{$23 \%$} \\
\hline To & & $100 \%$ & & \\
\hline
\end{tabular}
Perspectives

\section{B. Research Methodology}

Systematic problem solving is made so that the sequence of each stage in research can be understood easily. The following systematic problem solving for this research: Based on Figure 4., problem-solving starts with studying the guidance document on determining KPIs to SOEs and analyzing problems. There are 5 perspectives and 40 performance measures to choose from, so in the end, there will be 21 performance measures after performing AHP weighting. Finally, the proposed structural model design measures performance measures based on the KPI perspective.

\section{1) Process Hierarchy Structure}

Here are the results of choosing the number of performance measures for each perspective:

Based on Table 2, from the results of the questionnaire obtained, financial and market perspective has 4 performance measures to choose, customer focus perspective has 3 performance measures to choose, product and process effectiveness perspective has 4 performance measures to choose, workforce focus perspective has 2 performance measures to choose; and the perspective of leadership, governance, and social responsibility has 3 performance measures to choose from. Here is a figure of the process 
The $1^{\text {st }}$ International Conference on Business and Engineering Management (IConBEM 2020)

February $1^{\text {st }} 2020$, Institut Teknologi Sepuluh Nopember, Surabaya, Indonesia

hierarchy structure of performance measures:

Through the literature review [2], the following are the performance measures obtained for each perspective: (1)The Financial and Market Perspective has nine performance measures, namely income, income statement, cash position, net assets, debt leverage, cash-to-cash cycle time, earnings per share, financial operations efficiency (collection, billing, receivables), and financial returns; (2)Customer Focus Perspective has seven performance measures, namely customer satisfaction and dissatisfaction; retention, earnings, and loss of customers and customer accounts; customer complaints, complaint management, effective complaint resolution, and warranty claims; value perceived by customers based on quality and price; customer assessment of access and ease of use (including ethics in service interactions); customer support for brands and products offered; and awards, ratings, and recognition of customers and independent rating companies; (3)Product and Process Effectiveness Perspective has eleven performance measures for the appropriate product measures, measurements of internal quality, product performance, level of disability, misuse, responsiveness, data collected from customers by other companies regarding ease of use or attributes and customer surveys about product and service performance. In addition, measures and indicators of process effectiveness and efficiency are categorized into work system performance which shows increased cost savings or higher productivity using internal and/or external resources; reduced levels of emissions or energy consumption, reduction of waste flow, use of by-products, and recycling; indicators of internal responsiveness, such as cycle time, production flexibility, waiting time, installation time, and market time; and improving the performance of administrative functions and other supporting functions; (4)Workforce Focus Perspectives has eight performance measures, namely safety, absenteeism, turnover, satisfaction, and labor complaints. In addition, there are specific factors for measuring climate and the level of engagement of a company's workforce. Company-specific factors can be in the form of the effectiveness of training, retraining, or cross-functional training in meeting the capabilities and capabilities of the company's workforce; the effectiveness of the workforce independent (self-directing); and the effectiveness of union management-management partnerships; (5)The Leadership, Governance and Community Responsibility Perspective focus on the company's main results in the areas of senior leadership and governance aimed at showing financially and ethically established companies that fulfill their social responsibilities and support their main community. Reported results must include environmental, legal and regulatory compliance; results of oversight audits by government or funding agencies; and achievements worthy of note in this field. Results must also include the company's contribution to social welfare and the benefits and support to the main community.

The assignment of KPI weights serves as a sign to determine the acquisition of KPI scores from each KPKU perspective, KPKU perspective scores, and KPKU total scores. The weights of each perspective are arranged in
Figure 7 until Figure 10. as follows: (a) Companies with the majority of their main business are in industries that are growing rapidly (> 15\%); (b)Companies with the majority of their main businesses are in industries with moderate growth (5\% - 15\%); (c)Companies with industries where the majority of the main businesses are in industries whose growth is relatively slow ( $0 \%$ - 5\%); (d)Companies with the majority of their businesses are in industries with negative growth $(<0 \%)$ After determining the weights for each perspective, SOEs ratify the Management Contract (KM). The BUMN Directors set KPIs, performance targets for the planned year and other relevant information in the form of $\mathrm{KM}$ containing an introduction; goals and strategies; Key Performance Indicators (KPI) and targets; financial statement projections; shareholder directives and other key stakeholder aspirations; performance agreement. Towards the achievement of its performance, the Board of Directors proposes the amount of score per each KPI and the KPU perspective as well as the overall score with the stipulated achievement score per KPI.

\section{RESULT AND DISCUSSION}

Following are the selected results for each perspective: After normalizing the results of pairwise comparisons, priority vector calculations are performed for each performance measure to determine the chosen performance measure. Based on the majority of questionnaires completed by PT X experts, the number selected for financial and market perspectives is 4 performance measures out of a total of 7 performance measures. This selection is based on the company's strategic goals is increasing the company's revenue so that it can invest the business well [6]. Based on Table 3, 4 performance measures with the largest priority vector value are cash positions with a value of 0.194 , cash-tocash time cycle with a value of 0.185 , revenue with a value of 0.153 , and financial operations efficiency (collection, billing, receivables) with a value of 0.126 . With a consistency ratio of 0.05 , which is less than 0.1 so it is declared consistent and the results can be used by companies. After normalizing the results of pairwise comparisons, priority vector calculations are performed for each performance measure to determine the chosen performance measure. Based on the majority of questionnaires completed by PT X experts, the number selected for customer focus is 3 performance measures out of a total of 7 performance measures. This selection is based on the company's strategic goals is to build the company's image through good service to consumers [6]. Based on Table 4., the 3 performance measures with the largest priority vector value are customer complaints, complaint management, effective complaint resolution, and warranty claims with a value of 0.227 ; customer satisfaction and dissatisfaction with a value of 0.213 ; and customer retention, acquisition, and loss of customers and customer accounts with a value of 0.188 . With a consistency ratio of 0.06 , which is less than 0.1 so it is declared consistent and the results can be used by companies.

After normalizing the results of pairwise comparisons, priority vector calculations are performed for each performance measure to determine the chosen performance 
The $1^{\text {st }}$ International Conference on Business and Engineering Management (IConBEM 2020)

February $1^{\text {st }} 2020$, Institut Teknologi Sepuluh Nopember, Surabaya, Indonesia

measure. This selection is based on the company's strategic goals is to improve work performance to reduce costs due to defects [6]. Based on Table 5., 4 performance measures with the largest priority vector value are the performance of the product with a value of 0.16 ; work system performance which shows an increase in cost savings or higher productivity with a value of 0.15 ; increasing the performance of administrative functions and other supporting functions with a value of 0.12 ; and indicators of internal responsiveness, such as cycle time, production flexibility, waiting time, installation time, and time to market with a value of 0.10 . With a consistency ratio of 0.07 , which is less than 0.1 so it is declared consistent and the results can be used by companies.

After normalizing the results of pairwise comparisons, priority vector calculations are performed for each performance measure so that known performance measures are selected. This selection is based on the company's strategic goals is to maintain the turnover rate of $0 \%$ so employees can help the company in developing investments [6]. Based on Table 7., the 2 performance measures with the largest priority vector are the turnover with a value of 0.39 and the effectiveness of training, retraining, or crossfunctional training in meeting the capability and capacity requirements of a company's workforce with a value of 0.36 . With a consistency ratio of 0.08 , which is less than 0.1 so that it is declared consistent and the results can be used by companies.

After normalizing the results of pairwise comparisons, priority vector calculations are performed for each performance measure to determine selected performance measures. This selection is based on the company's strategic objectives, which are SOEs with the obligation to comply with all established regulations [6]. Based on Table 6., the 3 performance measures with the largest priority vector value are the company's contribution to social welfare and benefits and support to the main community with a value of 0.28 , achievements that are worthy of being recorded in this field with a value of 0.25 , and environmental, legal, and regulatory compliance with a value of 0.24 . With a consistency ratio of 0.06 , which is less than 0.1 so it is declared consistent and the results can be used by companies. After that, the adjustment results for the weighted performance measures for the company are medium growth business [6]. Thus, the weight of Financial and Market perspectives is $24 \%$, the weight of Customer Focus perspective is $22 \%$, the weight of Product Effectiveness and Process perspective is $20 \%$, the weight of Focus Workforce Leadership is 17\%, Governance, and Community Responsibility perspective is $17 \%$ as shown in Table 8 until Table.12.

KPKU conversion weights are obtained from a combination of KPKU calculations consisting of business growth and AHP weights obtained from size calculations that are in line with the company's strategic plan targets. Comparative analysis of existing performance appraisals and proposals includes differences between the assessments before and after the study. In the assessment of existing performance, companies have used the KPKU framework to measure company performance. However, the company has not used performance measures that match the number and weight with the KPKU guidelines. Therefore, the use of AHP in this study is to determine the performance measures to be chosen along with the weight of the performance itself so that SOE $\mathrm{X}$ does not need to involve all performance measures by focusing only on performance measures that are important to the company. The following is an assessment of the existing performance at SOE $\mathrm{X}$ as shown in Table 13.

\section{CONCLUSION}

Based on the research that has been done, it can be concluded that PT $\mathrm{X}$ as one of the companies under the Ministry of BUMN still has problems related to performance indicators in the form of the selection of performance indicators from KPKU because they do not reflect the company's strategic goals, have not been carried out with systematic calculations, and the numbers are not in accordance under the condition. Based on the majority of the questionnaires completed by 3 PT X experts, the following are the results of research on the number of each performance measure and the performance measure selected based on weight:

The financial and market perspective consists of cash positions, cash-to-cash time cycles, income, and financial operations efficiency (collection, billing, receivables). The customer focus perspective consists of customer complaints, complaint management, effective complaint resolution, and warranty claims; customer satisfaction and

dissatisfaction; and customer retention, acquisition, and loss of customers and customer accounts. The product and process effectiveness perspective consists of product performance; work system performance that shows increased cost savings or higher productivity; improved performance of administrative functions and other supporting functions; and indicators of internal responsiveness, such as cycle time, production flexibility, waiting time, installation time, and market time.

The workforce focus perspective consists of turnover and the effectiveness of training, retraining, or cross-functional training in meeting the capabilities and capabilities of the company's workforce. The leadership, governance, and community responsibility perspective consists of the company's contribution to social welfare and benefits and support to the main community, achievements that are worthy of note in this field, and environmental, legal, and regulatory compliance.

\section{REFERENCES}

[1] A. Wijayanti and S. Wimbarti, "Evaluasi dan pengembangan sistem penilaian kinerja pada pt hks,” J. Psikol. Undip, vol. 11, no. 2, p. 14, 2012, doi: 10.14710/jpu.11.2.14.

[2] “Pedoman Penentuan KPI pada BUMN,” KBUMN, 2013.

[3] B. Sulistyo, “Awareness and Implementation of Business Excellence Framework of Indonesia State-Owned Enterprises.,” 2019.

[4] M. Mohammad, "Business excellence model: an overarching framework for managing and aligning multiple organisational improvement initiatives,” pp. 4-6, 2016.

[5] P. X, “Annual Report: Innovating Beyond Excellence,” 2018.

[6] A. Febrianto, “Analisis pengukuran kinerja perusahaan dengan metode pendekatan balanced scorecard (studi kasus pada koperasi simpan 
The $1^{\text {st }}$ International Conference on Business and Engineering Management (IConBEM 2020)

February $1^{\text {st }} 2020$, Institut Teknologi Sepuluh Nopember, Surabaya, Indonesia

pinjam (ksp) lohjinawe rembang,” J. Ilmu Adm. Bisnis, vol. 5, no. 3, pp. 1-20, 2016,

[7] M. Situmorang and J. P. Marbun, "Perbandingan algoritma arithmetic dengan geometric mean filter untuk reduksi noise pada citra,” J. Ilmu Komput. dan Teknol. Inf. USU, 2012.
[8] E. W. Cheng and H. Li, "Analytic hierarchy process: an approach to determine measures for business performance,” Meas. Bus. Excell., vol. 5, no. 3, 2001.

[9] T. L. Saaty, Fundamental of Decision Making and Priority Theory with The Analytic. Pittsburgh: RWS Publication, 1994. 